\title{
GENETIC ANALYSIS FOR SEVEN PEA CULTIVARS (PISUM SATIVUM L.) USING LINE $\times$ TESTER METHOD FOR SEED YIELD AND ITS COMPONENTS IN F5 GENERATION UNDER SULAIMANI CONDITIONS
}

\author{
HAMA-AMIN, T. N. \\ Biotechnology and Crop Science Department, College of Agricultural Engineering Sciences, \\ Sulaimani, Iraq \\ (e-mail: taban.najmaddin@univsul.edu.iq,tabantaby@yahoo.com) \\ (Received $3^{\text {rd }}$ Feb 2020; accepted $9^{\text {th }}$ Jul 2020)
}

\begin{abstract}
Seven pea cultivars (Pisum sativum L.) were crossed in a line $\times$ tester mating design. The $12 \mathrm{~F}_{5}$ generation and their parents were evaluated using a completely randomized block design with three replications in Kurdistan Reign, Iraq at Qlyasan Agricultural Research Station, University of Sulaimani, during the winter season of 2015-2016. Heritability in a broad sense was high for all treats except number and seed weight pod ${ }^{-1}$ which were low, while in narrow sense it was low for all treats except average pod weight and 100-seed weight which were high. Highly significant and positive correlation was found between seed weight plant ${ }^{-1}$ with pod number plant ${ }^{-1}$, while highly significant and negative correlation was recorded between seed weight plant ${ }^{-1}$ with pod length and seed weight $\operatorname{pod}^{-1}$. Seed number pod ${ }^{-1}$ recorded maximum direct effect in seed weight plant $^{-1}$, while maximum positive indirect effect in seed weight plant ${ }^{-1}$ recorded by pod length via pod number plant ${ }^{-1}$. The present study was conducted to find out the relative importance of various yield traits for seed yield and to evaluate promising genotypes by mean of correlation and to find genetically diverse genotypes which can be used further in a various breeding program in developing wide yielding varieties.
\end{abstract}

Keywords: gene action, heterosis, heritability, combining ability, correlation and path analysis

\section{Introduction}

Pea (Pisum sativum L.) is a self-pollinated, diploid crop with 14 chromosomes $(2 \mathrm{n}=14)$. Pea originates from Near East and Mediterranean regions. It is one of the world's oldest crops cultivated as early as 9,000 years ago for human consumption and animals feed (Askander et al., 2018). Peas is one of the four of the most important cultivated legume and largest world's legume crop in the production after soybean, peanuts and dry beans (Yoshida et al., 2007 and Smykal et al., 2012).

Pea (Pisum sativum L.) is an important legume grown as a garden and field crop throughout the temperate regions of the world. Pea is valued primarily for the nutritional quality of its seeds. Pea protein is low in sulfur containing amino acids i.e. cysteine and methionine, but rich in lysine and other essential amino acids (Ceyhan and Avci, 2005). It is the source of protein having essential amino acids that have high nutritional values for resource poor households (Nawab et al., 2008). Moreover, some important minerals such as calcium, phosphorus and iron are also present in abundant quantities in pea which are lacking in cereals (Haque et al., 2014). Pea contains 20-25\% starch, 4-10\% sugar, 0.6-1.5\% fat and 2-4\% minerals (Makasheva, 1983). The present nutritional situation is a matter of great concern because most of the people are suffering from malnutrition (Mahbub et al., 2016).

The line $\times$ tester analysis method is used to breed both self and cross-pollinated plants and to estimates favorable parents and crosses, and their general and specific combining abilities (Kempthorne, 1957). Combining ability analysis is an important 
tool for the selection of desirable parents together with the information regarding nature and magnitude of gene effects controlling quantitative traits (Basbag et al., 2007). General combining ability and specific combining ability which identify the hybrids with high yield are the most important criteria in breeding programs (Ceyhan, 2003).

The knowledge of combining ability and nature of gene action is necessary for the selection of best parents for hybridization in order to improve the existing cultivars. It is also necessary to know the performance of a cross combination in comparison to the parents involved in the hybrids (Tampha et al., 2018).

The objective of this study was to measure the phenotypic variability of these traits, to obtain the general and specific combining ability, and to estimate heritability, heterosis, correlation and path analysis assess their potential use in breeding for winter season that suits the environmental conditions prevailing in the region.

\section{Materials and methods}

The present investigation was conducted at Qlyasan locations, in Kurdistan RegionIraq, Agricultural Research Station, College of Agricultural Engineering Sciences-

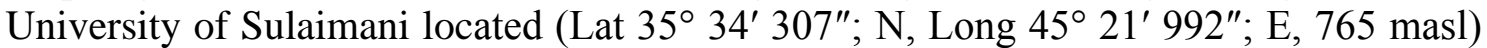
$2 \mathrm{~km}$ North West of Sulaimani City, during (2015-2016). The experimental material comprises seven pea cultivars (Pisum sativum L.). Three cultivars (1/Avolla, 2/America, $3 /$ Jeza) implemented as females, hereafter designated as lines, and four cultivars (4/Joneor, 5/Packland, 6/Arvena, 7/Samara) were used as males, fixed as testers (Table 1). All parental cultivars were crossed to produce $12 \mathrm{~F}_{1}$ crosses according to the line $\times$ tester mating design assessed by Kempthorne (1957). $F_{1}$ seeds were sown in the field, along with their parents, in Complete Randomize Block Design with three replication. Each plot comprised one row of $2 \mathrm{~m}$ length with space of $40 \mathrm{~cm}$ between rows and seeds were placed $20 \mathrm{~cm}$ apart. Five competitive plants (excluding border plants) were chosen and data were recorded for: Pods number plant ${ }^{-1}$, pods weight plant ${ }^{-}$ 1 , pod length, average pod weight, seeds number $\operatorname{pod}^{-1}$, seeds weight pod $^{-1}$, 100-seed weight, biological weight plant ${ }^{-1}$ and seeds weight plant $^{-1}$.

Table 1. Studied breeding materials

\begin{tabular}{c|c|c|c|c}
\hline \multirow{2}{*}{ Line parent } & \multicolumn{4}{|c}{ Tester parent } \\
\cline { 2 - 5 } & 4- Joneor & 5- Packland & 6- Arvena & 7-Samara \\
\hline \multirow{2}{*}{ 1-Avolla } & $1 \times 4$ & $1 \times 5$ & $1 \times 6$ & $1 \times 7$ \\
& Avolla $\times$ Joneor & Avolla $\times$ Packland & Avolla $\times$ Arvena & Avolla $\times$ Samara \\
\hline \multirow{2}{*}{ 2-America } & $2 \times 4$ & $2 \times 5$ & $2 \times 6$ & $2 \times 7$ \\
& America $\times$ Joneor & America $\times$ Packland & America $\times$ Arvena & America $\times$ Samara \\
\hline \multirow{2}{*}{ 3-Jeza } & $3 \times 4$ & $3 \times 5$ & $3 \times 6$ & $3 \times 7$ \\
& Jeza $\times$ Joneor & Jeza $\times$ Packland & Jeza $\times$ Arvena & Jeza $\times$ Samara \\
\hline
\end{tabular}

Genetic parameters: general combining ability (gca) and effects, specific combining ability (sca) and effects, heterosis percentage as the $F_{1}$ s deviation from average parental values, heritability in broad sense, heritability in narrow sense, average degree of dominance $(\bar{a})$, correlation and path coefficient analysis. The collected data were submitted to analysis of variance as proposed by Al-Mohammad and Al-Yonis (2000) to estimate significant differences among cultivars. Combining ability effects are very 
important genetic parameters in determining the next phase of breeding programs. They were computed according to the line $\times$ tester method (Singh and Chaudhary, 1985) (Table 2).

Table 2. Analysis of variance according to line $\times$ tester design (Singh and Chaudhary, 1985)

\begin{tabular}{|c|c|c|c|}
\hline S.O.V & d.f & SS & MS \\
\hline Replicates & $(r-1)$ & $S S_{R}=\frac{\sum Y_{. . k}^{2}}{g}-C . F($ Over all $)$ & $M S R$ \\
\hline Genotypes & $(g-1)$ & $S S_{G}=\frac{\sum \sum C_{i j}^{2}+\sum \sum P_{i i .}^{2}}{r}-C . F($ Over all $)$ & $M S G$ \\
\hline Parents & $(P-1)$ & $S S_{P}=\frac{\sum \sum P_{i i .}^{2}}{r}-C . F($ Parents $)$ & $M S P$ \\
\hline Crosses & $(L t-1)$ & $S S_{C}=\frac{\sum \sum C_{i j}^{2}}{r}-C . F($ Crosses $)$ & $M S C$ \\
\hline Parents vs. Crosses & 1 & $\begin{aligned} S S_{P \text { vs. } .} & =S S_{G}-S S_{p}-S S_{C} \\
& =C . F(\text { Parents })+C . F(\text { Crosses }) \\
& -C . F(\text { Over all })\end{aligned}$ & $M S P$ vs. $C$ \\
\hline Lines & $(L-1)$ & $S S_{L}=\frac{\sum C_{i .}^{2}}{r t}-C . F($ Crosses $)$ & $M S L$ \\
\hline Testers & $(T-1)$ & $S S_{T}=\frac{\sum C_{. j}^{2}}{r l}-C . F($ Crosses $)$ & $M S T$ \\
\hline Lines $\times$ Testers & $(L-1)(T-1)$ & $S S_{L x T}=S S_{C}-S S_{L}-S S_{T}$ & $M S L \times T$ \\
\hline Error & $(r-1)(g-1)$ & $S S e=S S T-S S R-S S G$ & $M S e$ \\
\hline Total & $(r g-1)$ & $S S_{\text {Total }}=\sum Y_{i j k}^{2}-C . F($ Over all $)$ & \\
\hline
\end{tabular}

$\mathrm{R}=$ replication $; \mathrm{L}=$ line $; \mathrm{T}=$ tester $\mathrm{G}=$ genotypes

\section{Results}

Data in (Table 3) illustrate the significance of ANOVA table components due to studied characters. The mean squares due to genotypes and parents were highly significant for all characters, while the mean squares due to parent's $\times$ crosses were highly significant for only pod weight plant $^{-1}$, pod length, biological yield plant ${ }^{-1}$ and seed weight plant $^{-1}$. The mean squares due to crosses were highly significant for all characters except seed number pod $^{-1}$ which was significant only. The mean squares due to lines, there were highly significant mean squares for all characters except seed number and weight pod $^{-1}$ which were only significant. The mean squares estimated for testers were highly significant for all characters except pod length which was significant only, but the characters seed number $\operatorname{pod}^{-1}$ and 100 -seed weight were not significant. The mean squares due to line $\times$ tester were highly significant for all characters except average pod weight ${ }^{-1}$, seed number pod $^{-1}$, seed weight pod $^{-1}$ and 100 -seed weight which were not significant. 
Table 3. ANOVA table for the studied characters

\begin{tabular}{|c|c|c|c|c|c|c|c|c|c|c|}
\hline \multirow[b]{2}{*}{ S.O.V } & \multirow[b]{2}{*}{ d.f } & \multicolumn{9}{|c|}{ M.S } \\
\hline & & $\begin{array}{l}\text { Pods no. } \\
\text { plant }^{-1}\end{array}$ & $\mid \begin{array}{c}\text { Pods weight } \\
\text { plant }^{-1}(\mathrm{~g})\end{array}$ & $\begin{array}{c}\text { Pod } \\
\text { length } \\
(\mathrm{cm})\end{array}$ & $\begin{array}{c}\text { Average } \\
\text { pod } \\
\text { weight }(\mathrm{g})\end{array}$ & $\begin{array}{c}\text { Seeds } \\
{\text { no. } \text { pod }^{-1}}^{-1} \\
\end{array}$ & $\begin{array}{c}\text { Seeds } \\
\text { weight } \\
\operatorname{pod}^{-1}(g)\end{array}$ & $\begin{array}{c}100 \text {-seed } \\
\text { weight }(\mathrm{g})\end{array}$ & $\begin{array}{c}\text { Biological } \\
\text { weight } \\
\text { plant }^{-1}(\mathrm{~g}) \\
\end{array}$ & $\begin{array}{c}\text { Seeds } \\
\text { weight } \\
\text { plant }^{-1}(g)\end{array}$ \\
\hline Blocks & 2 & 13.806 & 6.339 & 0.684 & 0.001 & 0.989 & 0.001 & 1.739 & 5.183 & 0.104 \\
\hline Genotype & 18 & $\begin{array}{c}* * \\
185.155\end{array}$ & $\begin{array}{c}* * \\
97.461\end{array}$ & $\begin{array}{c}* * \\
5.010\end{array}$ & $\begin{array}{c}* * * \\
0.077\end{array}$ & $\begin{array}{c}* * * \\
0.930\end{array}$ & $\begin{array}{c}* * * \\
0.027\end{array}$ & $\begin{array}{c}* * \\
53.854\end{array}$ & $\begin{array}{c}* * \\
171.552\end{array}$ & $\begin{array}{c}* * \\
11.968\end{array}$ \\
\hline Parents & 6 & $\begin{array}{c}* * \\
244.543 \\
\end{array}$ & $\begin{array}{c}* * \\
108.926\end{array}$ & $\begin{array}{c}* * * \\
6.635\end{array}$ & $\begin{array}{c}* * \\
0.116\end{array}$ & $\begin{array}{c}* * \\
1.908\end{array}$ & $\begin{array}{c}* * \\
0.046\end{array}$ & $\begin{array}{c}* * \\
74.543\end{array}$ & $\begin{array}{c}* * \\
283.103\end{array}$ & $\begin{array}{c}* * \\
23.206\end{array}$ \\
\hline $\begin{array}{c}\text { Parents } \times \\
\text { Crosses } \\
\end{array}$ & 1 & $\begin{array}{c}\text { n.s } \\
2.087 \\
\end{array}$ & $\begin{array}{c}* * * \\
200.246 \\
\end{array}$ & $\begin{array}{c}* * * \\
8.949 \\
\end{array}$ & $\begin{array}{c}\mathrm{n} . \mathrm{s} \\
0.070 \\
\end{array}$ & $\begin{array}{c}\text { n.s } \\
0.165 \\
\end{array}$ & $\begin{array}{c}\text { n.s } \\
0.015 \\
\end{array}$ & $\begin{array}{c}\mathrm{n} . \mathrm{s} \\
0.016 \\
\end{array}$ & $\begin{array}{c}* * \\
414.141 \\
\end{array}$ & $\begin{array}{c}* * * \\
2.981 \\
\end{array}$ \\
\hline Crosses & 11 & $\begin{array}{c}* * \\
169.404\end{array}$ & $\begin{array}{c}* * \\
81.863\end{array}$ & $\begin{array}{c}* * \\
3.765\end{array}$ & $\begin{array}{c}* * \\
0.056\end{array}$ & $\begin{array}{c}* * \\
0.467\end{array}$ & $\begin{array}{c}* * * \\
0.018\end{array}$ & $\begin{array}{c}* * * \\
47.463\end{array}$ & $\begin{array}{c}* * \\
88.654\end{array}$ & $\begin{array}{c}* * \\
6.655\end{array}$ \\
\hline Lines & 2 & $\begin{array}{c}* * \\
315.131 \\
\end{array}$ & $\begin{array}{c}* * \\
153.621 \\
\end{array}$ & $\begin{array}{c}* * \\
6.583 \\
\end{array}$ & $\begin{array}{c}* * \\
0.109 \\
\end{array}$ & $\begin{array}{c}* \\
1.285\end{array}$ & $\begin{array}{c}* \\
0.028 \\
\end{array}$ & $\begin{array}{c}* * \\
249.440\end{array}$ & $\begin{array}{c}* * \\
30.184 \\
\end{array}$ & $\begin{array}{c}* * * \\
7.977\end{array}$ \\
\hline Testers & 3 & $\begin{array}{c}* * \\
160.380 \\
\end{array}$ & $\begin{array}{c}* * * \\
46.237 \\
\end{array}$ & $\begin{array}{c}* * \\
4.324 \\
\end{array}$ & $\begin{array}{c}* * * \\
0.121 \\
\end{array}$ & $\begin{array}{c}\mathrm{n} . \mathrm{s} \\
0.264 \\
\end{array}$ & $\begin{array}{c}* * * \\
0.026 \\
\end{array}$ & $\begin{array}{c}\mathrm{n} . \mathrm{s} \\
2.876 \\
\end{array}$ & $\begin{array}{c}* * \\
131.000 \\
\end{array}$ & $\begin{array}{c}* * * \\
6.503 \\
\end{array}$ \\
\hline Lines $\times$ Testers & 6 & $\begin{array}{c}* * * \\
125.340 \\
\end{array}$ & $\begin{array}{c}* * \\
75.756 \\
\end{array}$ & $\begin{array}{c}* * \\
2.546 \\
\end{array}$ & $\begin{array}{c}\text { n.s } \\
0.007 \\
\end{array}$ & $\begin{array}{c}\mathrm{n} . \mathrm{s} \\
0.296 \\
\end{array}$ & $\begin{array}{c}\text { n.s } \\
0.010 \\
\end{array}$ & $\begin{array}{c}\text { n.s } \\
2.431\end{array}$ & $\begin{array}{c}* * * \\
86.970 \\
\end{array}$ & $\begin{array}{c}* * \\
6.291 \\
\end{array}$ \\
\hline Error & 36 & 0.582 & 0.623 & 0.592 & 0.004 & 0.223 & 0.005 & 1.088 & 0.359 & 0.159 \\
\hline
\end{tabular}

Data in (Table 4) explain the average of studied characters for parents and their $\mathrm{F}_{5}$ crosses. Maximum value for pod number plant ${ }^{-1}$ produced by the cross $1 \times 6$ with 35.256, while for pod weight plant ${ }^{-1}$ it was produced by the cross $2 \mathrm{x} 4$ with $35.125 \mathrm{~g}$, whist for average pod weight produced by the cross 2 x 5 with $1.493 \mathrm{~g}$. Maximum value for pod length, seed weight pod $^{-1}$ and biological weight plant ${ }^{-1}$ produced by the cross $2 \times 6$ with $8.000 \mathrm{~cm}, 1.281 \mathrm{~g}$ and $40.375 \mathrm{~g}$ respectively. The cross $2 \times 7$ showed maximum value for 100 -seed weight with $23.392 \mathrm{~g}$. The cross $3 \times 6$ accepted the highest value for pod length and seed number pod $^{-1}$ with $8.000 \mathrm{~cm}$ and 6.033 . Maximum value for see weight plant $^{-1}$ produced by the cross $1 \times 4$ with $17.338 \mathrm{~g}$. The same table illustrates the average of characters due to the parents, parent 2 produced the highest value for pod length and 100-seed weight with $8.000 \mathrm{~cm}$ and $28.253 \mathrm{~g}$. Parent 3 exhibited the highest value for seed number pod $^{-1}$ and seed weight pod ${ }^{-1}$ with 6.833 and $1.277 \mathrm{~g}$. The highest value due to pod number plant ${ }^{-1}$, biological weight plant $^{-1}$ and seed weight plant ${ }^{-1}$ produced by parent 6 with $36.929,44.195 \mathrm{~g}$ and 20.268 g. Parent 7 gave the highest value for pod weight plant ${ }^{-1}$ and average pod weight with $30.389 \mathrm{~g}$ and $1.577 \mathrm{~g}$. The lowest value due to almost most characters produced by parent 5 and 6 .

Table 5 explains the heterosis values estimated as the percentage of $\mathrm{F}_{5} \mathrm{~s}$ deviated from mid parental values. Maximum positive heterosis values for pod number plant ${ }^{-1}$, average pod weight and seed number pod ${ }^{-1}$ were $20.115,7.207$ and $2.719 \%$ respectively produced by the cross $2 \times 5$, while the cross $2 \times 6$ produced maximum positive value for seed weight pod $^{-1}$ and 100 -seed weight with 5.031 and $3.932 \%$. The cross $3 \times 5$ gave the highest positive heterosis value for pod weight plant $^{-1}$ and biological weight plant $^{-1}$ with 22.989 and $23.703 \%$. The highest heterosis positive value for pod length was $11.364 \%$ produced by the cross $3 \times 6$, while for seed weight plant $^{-1}$ it was $4.401 \%$ produced by the cross $1 \times 4$. The cross $3 \times 7$ showed maximum negative heterosis values for most characters. The positive value due to heterosis ratify the over dominance gene effect for the parent with high value, while the negative heterosis value signify the partial dominance gene effect for the parent with low value. 
Table 4. Averages of studied characters for parents and their $F_{5}$ crosses

\begin{tabular}{|c|c|c|c|c|c|c|c|c|c|}
\hline $\begin{array}{c}\text { Crosses and } \\
\text { parents }\end{array}$ & $\begin{array}{c}\text { Pods no. } \\
\text { plant }^{-1}\end{array}$ & $\begin{array}{c}\text { Pods } \\
\text { weight } \\
\text { plant }^{-1}(g)\end{array}$ & $\begin{array}{l}\text { Pod length } \\
\text { (cm) }\end{array}$ & $\begin{array}{c}\text { Average pod } \\
\text { weight (g) }\end{array}$ & $\begin{array}{c}\text { Seeds no. } \\
\text { pod }^{-1}\end{array}$ & $\begin{array}{c}\text { Seeds } \\
\text { weight } \\
\text { pod }^{-1}(g)\end{array}$ & $\begin{array}{c}100 \text {-seed } \\
\text { weight }(g)\end{array}$ & $\begin{array}{c}\text { Biological } \\
\text { weight } \\
\text { plant }^{-1}(g)\end{array}$ & $\begin{array}{c}\text { Seeds } \\
\text { weight } \\
\text { plant }^{-1}(g)\end{array}$ \\
\hline $1 \times 4$ & 34.822 & 26.862 & 5.000 & 1.117 & 5.333 & 1.037 & 14.372 & 35.070 & 17.338 \\
\hline $1 \times 5$ & 24.087 & 28.472 & 6.333 & 1.350 & 4.967 & 1.213 & 14.320 & 35.134 & 13.150 \\
\hline $1 \times 6$ & 35.256 & 24.663 & 5.000 & 1.231 & 5.133 & 1.036 & 14.175 & 40.219 & 15.249 \\
\hline $1 \times 7$ & 27.858 & 26.385 & 5.333 & 1.079 & 5.167 & 1.049 & 16.122 & 35.249 & 14.517 \\
\hline $2 \times 4$ & 33.441 & 35.125 & 5.667 & 1.394 & 4.667 & 1.134 & 22.306 & 20.467 & 14.317 \\
\hline $2 \times 5$ & 23.185 & 23.147 & 5.333 & 1.493 & 5.267 & 1.178 & 23.075 & 33.177 & 14.085 \\
\hline $2 \times 6$ & 17.999 & 27.508 & 8.000 & 1.375 & 5.433 & 1.281 & 22.467 & 40.375 & 13.350 \\
\hline $2 \times 7$ & 24.432 & 30.379 & 7.000 & 1.276 & 5.167 & 1.126 & 23.392 & 40.261 & 14.458 \\
\hline $3 \times 4$ & 24.531 & 23.320 & 5.333 & 1.213 & 5.600 & 1.086 & 14.044 & 34.088 & 14.271 \\
\hline $3 \times 5$ & 29.269 & 29.780 & 7.000 & 1.448 & 6.000 & 1.176 & 16.793 & 40.249 & 15.202 \\
\hline $3 \times 6$ & 16.073 & 19.734 & 8.000 & 1.380 & 6.033 & 1.177 & 15.085 & 35.158 & 11.132 \\
\hline $3 \times 7$ & 11.256 & 15.139 & 7.000 & 1.128 & 5.200 & 1.078 & 14.439 & 35.318 & 13.195 \\
\hline 1 & 26.592 & 25.299 & 5.000 & 1.048 & 5.000 & 1.131 & 14.118 & 25.145 & 15.145 \\
\hline 2 & 15.400 & 23.470 & 8.000 & 1.156 & 5.000 & 1.206 & 26.253 & 35.136 & 11.166 \\
\hline 3 & 26.188 & 20.286 & 7.000 & 1.403 & 6.833 & 1.277 & 16.119 & 27.264 & 13.239 \\
\hline 4 & 30.035 & 20.336 & 5.000 & 1.081 & 5.200 & 0.975 & 13.171 & 36.395 & 14.334 \\
\hline 5 & 10.296 & 10.742 & 4.333 & 1.162 & 4.500 & 1.111 & 21.119 & 14.057 & 14.409 \\
\hline 6 & 36.929 & 23.412 & 4.000 & 1.095 & 5.500 & 0.927 & 12.575 & 44.195 & 20.268 \\
\hline 7 & 28.073 & 30.389 & 4.667 & 1.577 & 4.500 & 1.051 & 19.242 & 26.472 & 14.079 \\
\hline $\operatorname{LSD}(\mathrm{p} \leq 0.05)$ & 1.263 & 1.307 & 1.274 & 0.105 & 0.782 & 0.117 & 1.727 & 0.993 & 0.660 \\
\hline
\end{tabular}

Table 5. \% Heterosis values for $F_{5}$ crosses of the studied characters

\begin{tabular}{|c|c|c|c|c|c|c|c|c|c|}
\hline Crosses & $\begin{array}{c}\text { Pods no. } \\
\text { plant }^{-1}\end{array}$ & $\begin{array}{c}\text { Pods } \\
\text { weight } \\
\text { plant }^{-1}(g)\end{array}$ & $\begin{array}{l}\text { Pod length } \\
\text { (cm) }\end{array}$ & $\begin{array}{c}\text { Average } \\
\text { pod weight } \\
\text { (g) }\end{array}$ & $\begin{array}{c}\text { Seeds no. } \\
\text { pod }^{-1}\end{array}$ & $\begin{array}{c}\text { Seeds } \\
\text { weight } \\
\operatorname{pod}^{-1}(g)\end{array}$ & $\begin{array}{c}100 \text {-seed } \\
\text { weight }(\mathrm{g})\end{array}$ & $\begin{array}{c}\text { Biological } \\
\text { weight plant }^{-1} \\
\text { (g) }\end{array}$ & $\begin{array}{c}\text { Seeds weight } \\
\text { plant }^{-1}(\mathrm{~g})\end{array}$ \\
\hline $1 \times 4$ & 5.747 & 4.4310 & 0.000 & 1.221 & 1.144 & -0.388 & 1.332 & 3.494 & 4.401 \\
\hline $1 \times 5$ & 7.649 & 14.500 & 8.929 & 5.543 & 1.140 & 2.052 & -4.681 & 19.812 & -2.753 \\
\hline $1 \times 6$ & 2.751 & 0.315 & 2.778 & 3.717 & -0.556 & 0.158 & 1.553 & 4.001 & -3.470 \\
\hline $1 \times 7$ & 0.481 & -1.310 & 2.586 & -4.457 & 2.193 & -0.974 & -0.836 & 9.145 & -0.162 \\
\hline $2 \times 4$ & 11.801 & 15.092 & -3.205 & 6.149 & -2.124 & 0.998 & 3.290 & -10.694 & 3.073 \\
\hline $2 \times 5$ & 20.115 & 8.827 & -3.378 & 7.207 & 2.719 & 0.428 & -0.645 & 8.721 & 2.536 \\
\hline $2 \times 6$ & -7.802 & 4.338 & 8.333 & 5.533 & 0.873 & 5.031 & 3.932 & 0.447 & -3.765 \\
\hline $2 \times 7$ & 3.100 & 3.203 & 2.632 & -1.655 & 2.193 & -0.052 & 0.708 & 7.675 & 3.635 \\
\hline $3 \times 4$ & -3.184 & 3.703 & -2.778 & -0.584 & -1.731 & -0.888 & -1.026 & 1.774 & 0.879 \\
\hline $3 \times 5$ & 15.112 & 22.989 & 5.882 & 3.223 & 1.471 & -0.363 & -2.452 & 23.703 & 2.493 \\
\hline $3 \times 6$ & -12.267 & -2.420 & 11.364 & 2.615 & -0.541 & 1.713 & 1.286 & -0.400 & -8.389 \\
\hline $3 \times 7$ & -14.628 & -10.062 & 5.000 & -6.074 & -2.059 & -1.837 & -4.584 & 7.8623 & -0.850 \\
\hline S.E & 3.074 & 2.580 & 1.423 & 1.236 & 0.500 & 0.524 & 0.795 & 2.619 & 1.101 \\
\hline
\end{tabular}

*S.E: standard error of the estimation

Table 6 illustrates the estimation of gca effect for parents due to studied characters. Maximum positive gca effect for pod number plant $^{-1}$ was 5.747 produced by tester parent 4, while for pod weight plant $^{-1}$ and 100-seed weight were 3.164 and 5.261 respectively produced by line parent 2 . Maximum positive gca effect value for pod length and biological weight plant ${ }^{-1}$ were 0.750 and 3.187 respectively produced by tester parent 6 . The tester parent 5 showed maximum positive gca effect value for average pod weight with 0.140 . The line parent 3 exhibited the highest positive gca 
effect for seed number pod $^{-1}$ with 0.387 . The tester parent 5 showed maximum gca effect value for seed weight pod $^{-1}$ with 0.058 , while for seed weight plant $^{-1}$ was 1.120 produced by tester parent 4 . Maximum negative gca effect value for pod number plant ${ }^{-1}$ was -4.902 and for pod weight plant ${ }^{-1}$ was -3.883 produced by tester parent 3 , while for 100 -seed weight and biological weight plant $^{-1}$ was -2.802 and -5.522 produced by line parent 1 and tester parent 4 respectively. The positive value of gca indicated to the tendency of these parents to increase the value of this character, while the negative gca value indicate to the ability of these parents to reduce the value of this character.

Table 6. Estimation of general combining ability ( $\mathrm{gca}$ ) effect for the parents of the studied characters

\begin{tabular}{c|c|c|c|c|c|c|c|c|c}
\hline Parents & $\begin{array}{c}\text { Pods no. } \\
\text { plant }^{-1}\end{array}$ & $\begin{array}{c}\text { Pods } \\
\text { weight } \\
\text { plant }^{-1}(\mathbf{g})\end{array}$ & $\begin{array}{c}\text { Pod length } \\
(\mathbf{c m})\end{array}$ & $\begin{array}{c}\text { Average } \\
\text { pod weight } \\
(\mathbf{g})\end{array}$ & $\begin{array}{c}\text { Seeds no. } \\
\text { pod }^{-1}\end{array}$ & $\begin{array}{c}\text { Seeds weight } \\
\text { pod }^{-1}(\mathbf{g})\end{array}$ & $\begin{array}{c}\text { 100-seed } \\
\text { weight }(\mathbf{g})\end{array}$ & $\begin{array}{c}\text { Biological } \\
\text { weight plant } \\
(\mathbf{- 1})\end{array}$ & $\begin{array}{c}\text { Seeds } \\
\text { weight }_{\text {plant }^{-1}(\mathbf{g})}\end{array}$ \\
\hline 1 & 5.322 & 0.719 & -0.833 & -0.096 & -0.181 & -0.047 & -2.802 & 1.021 & 0.875 \\
2 & -0.420 & 3.164 & 0.250 & 0.094 & -0.197 & 0.049 & 5.261 & -1.827 & -0.136 \\
3 & -4.902 & -3.883 & 0.583 & 0.002 & 0.378 & -0.002 & -2.459 & 0.806 & -0.739 \\
S.E lines & 0.220 & 0.228 & 0.222 & 0.018 & 0.136 & 0.020 & 0.301 & 0.173 & 0.115 \\
4 & 5.747 & 2.559 & -0.917 & -0.049 & -0.131 & -0.046 & -0.642 & -5.522 & 1.120 \\
5 & 0.330 & 1.257 & -0.028 & 0.140 & 0.081 & 0.058 & 0.513 & 0.790 & -0.043 \\
6 & -2.075 & -1.908 & 0.750 & 0.038 & 0.203 & 0.034 & -0.307 & 3.187 & -0.945 \\
7 & -4.002 & -1.908 & 0.194 & -0.129 & -0.153 & -0.047 & 0.435 & 1.546 & -0.132 \\
S.E testers & 0.254 & 0.263 & 0.256 & 0.021 & 0.157 & 0.023 & 0.348 & 0.200 & 0.133 \\
\hline
\end{tabular}

The estimation of the sca effect of crosses represent in (Table 7). The highest positive effect for seed number pod $^{-1}$ produced by the cross $1 \times 4$ with 0.314 , while the cross $1 \times 5$ showed maximum positive sca effect for pod length and seed weight pod $^{-1}$ with 0.944 and 0.071 respectively, but for average pod weight it was 0.058 produced by the cross $2 \times 4$ and for biological weight plant $^{-1}$ it was 5.145 produced by the cross $2 \times 7$. The cross $3 \times 5$ produced maximum sca effect value for pod number plant $^{-1}$, pod weight plant $^{-1}, 100$-seed weight and seed weight plant $^{-1}$ with $8.657,6.530,1.189$ and 1.795 respectively. Maximum negative sca effect value for pod number plant $^{-1}$ and seed weight plant ${ }^{-1}$ was -6.748 and -1.871 produced by the cross $1 \times 5$, while for pod length and seed weight pod $^{-1}$ it was -1.167 and -0.082 produced by the cross $1 \times 6$. The cross $2 \times 4$ showed maximum negative sca effect for biological weight plant $^{-1}$ with -7.581 and for pod weight plant ${ }^{-1}$ it was -7.150 produced by the cross $2 \times 5$, while for average pod weight it was -0.048 produced by the cross $2 \times 6$, but for both seed number plant ${ }^{-1}$ and 100 -seed weight it was -0.356 and -1.086 respectively produced by the cross $3 \times 7$.

The estimation of some genetic parameters for the studied characters represent in (Table 8 ). The ratio of $\sigma_{\mathrm{gca}}^{2} / \sigma_{\text {sca }}^{2}$ for all characters was less than unity except average pod weight and 100-seed weight which were more than unity. The average degree of dominance was more than unity for all characters except average pod weight and 100seed weight, this indicate to the over dominance gene effect in controlling the inheritance of most characters. Heritability in broad sense was found to be high for most characters except the characters seed number pod $^{-1}$ and seed weight pod $^{-1}$ in which they found to be low. The estimation of heritability in narrow sense was low for all characters except the characters average pod weight and 100-seed weights which were recorded high estimation. 
Table 7. Estimation of specific combining ability (sca) for the $F_{1}$ crosses of the studied characters

\begin{tabular}{|c|c|c|c|c|c|c|c|c|c|}
\hline Crosses & \begin{tabular}{|c|} 
Pods no. \\
plant $^{-1}$
\end{tabular} & $\begin{array}{c}\text { Pods weight } \\
\text { plant }^{-1}(\mathrm{~g})\end{array}$ & $\begin{array}{c}\text { Pod length } \\
(\mathrm{cm})\end{array}$ & $\begin{array}{c}\text { Average pod } \\
\text { weight (g) }\end{array}$ & 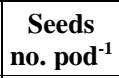 & $\begin{array}{c}\text { Seeds weight } \\
\text { pod }^{-1}(\mathrm{~g})\end{array}$ & $\begin{array}{c}100 \text {-seed } \\
\text { weight }(\mathrm{g})\end{array}$ & \begin{tabular}{|c|} 
Biological \\
weight plant $^{-1}(\mathrm{~g})$
\end{tabular} & $\begin{array}{l}\text { Seeds weight } \\
\text { plant }^{-1}(\mathrm{~g})\end{array}$ \\
\hline $1 \times 4$ & -1.431 & -2.293 & 0.500 & -0.028 & 0.314 & -0.001 & 0.266 & 4.174 & 1.155 \\
\hline $1 \times 5$ & -6.748 & 0.620 & 0.944 & 0.016 & -0.264 & 0.071 & -0.941 & -2.073 & -1.871 \\
\hline $1 \times 6$ & 6.825 & -0.025 & -1.167 & -0.001 & -0.219 & -0.082 & -0.265 & 0.614 & 1.130 \\
\hline $1 \times 7$ & 1.355 & 1.698 & -0.278 & 0.014 & 0.169 & 0.012 & 0.940 & -2.715 & -0.414 \\
\hline $2 \times 4$ & 2.929 & 3.526 & 0.083 & 0.058 & -0.336 & -0.000 & 0.138 & -7.581 & -0.855 \\
\hline $2 \times 5$ & -1.909 & -7.150 & -1.139 & -0.031 & 0.053 & -0.060 & -0.249 & -1.183 & 0.075 \\
\hline $2 \times 6$ & -4.690 & 0.376 & 0.750 & -0.048 & 0.097 & 0.068 & -0.036 & 3.619 & 0.243 \\
\hline $2 \times 7$ & 3.670 & 3.248 & 0.306 & 0.021 & 0.186 & -0.007 & 0.147 & 5.145 & 0.538 \\
\hline $3 \times 4$ & -1.498 & -1.233 & -0.583 & -0.030 & 0.022 & 0.002 & -0.404 & 3.407 & -0.299 \\
\hline $3 \times 5$ & 8.657 & 6.530 & 0.194 & 0.016 & 0.211 & -0.011 & 1.189 & 3.256 & 1.795 \\
\hline $3 \times 6$ & -2.134 & -0.352 & 0.417 & 0.049 & 0.122 & 0.014 & 0.301 & -4.232 & -1.373 \\
\hline $3 \times 7$ & -5.025 & -4.945 & -0.028 & -0.035 & -0.356 & -0.005 & -1.086 & -2.431 & -0.123 \\
\hline S.E & 0.623 & 0.644 & 0.628 & 0.0517 & 0.386 & 0.057 & 0.852 & 0.490 & 0.325 \\
\hline
\end{tabular}

Table 8. Estimation of some genetic parameters for the studied characters

\begin{tabular}{|c|c|c|c|c|c|c|c|c|c|}
\hline Parameters & $\begin{array}{c}\text { Pods no. } \\
\text { plant }^{-1}\end{array}$ & $\begin{array}{c}\begin{array}{c}\text { Pods } \\
\text { weight } \\
\text { plant }^{-1}(g)\end{array} \\
\end{array}$ & $\begin{array}{c}\text { Pod } \\
\text { length } \\
\text { (cm) }\end{array}$ & $\begin{array}{c}\text { Average } \\
\text { pod weight } \\
\text { (g) }\end{array}$ & $\begin{array}{c}\text { Seeds no. } \\
\text { pod }^{-1}\end{array}$ & $\begin{array}{c}\text { Seeds } \\
\text { weight } \\
\operatorname{pod}^{-1}(g)\end{array}$ & $\begin{array}{c}100 \text {-seed } \\
\text { weight }(\mathrm{g})\end{array}$ & $\begin{array}{c}\begin{array}{c}\text { Biological } \\
\text { weight plant }^{-1} \\
(\mathrm{~g})\end{array} \\
\end{array}$ & $\begin{array}{c}\begin{array}{c}\text { Seeds } \\
\text { weight } \\
\text { plant }^{-1}(g)\end{array} \\
\end{array}$ \\
\hline$\sigma^{2} \mathrm{e}$ & 0.582 & 0.623 & 0.592 & 0.004 & 0.223 & 0.005 & 1.088 & 0.359 & 0.159 \\
\hline$\sigma_{\mathrm{gca}}^{2}$ & 2.851 & 0.395 & 0.079 & 0.003 & 0.011 & 0.000 & 2.914 & 0.109 & 0.024 \\
\hline$\sigma_{\text {sca }}^{2}=\sigma_{D}^{2}$ & 41.586 & 25.044 & 0.652 & 0.001 & 0.024 & 0.002 & 0.448 & 28.870 & 2.044 \\
\hline$\sigma_{\mathrm{gca}}^{2} / \sigma_{\mathrm{sca}}^{2}$ & 0.069 & 0.016 & 0.121 & 3.756 & 0.458 & 0.281 & 6.509 & 0.004 & 0.012 \\
\hline$\sigma_{\mathrm{A}}^{2}$ & 5.702 & 0.790 & 0.158 & 0.006 & 0.022 & 0.001 & 5.828 & 0.218 & 0.047 \\
\hline $\bar{a}$ & 3.819 & 7.961 & 2.874 & 0.516 & 1.478 & 1.886 & 0.392 & 16.280 & 9.309 \\
\hline $\mathrm{h}_{\text {b.s }}^{2}$ & 0.988 & 0.976 & 0.578 & 0.645 & 0.172 & 0.356 & 0.852 & 0.988 & 0.929 \\
\hline $\mathrm{h}^{2}{ }_{\mathrm{n} . \mathrm{s}}$ & 0.119 & 0.030 & 0.113 & 0.569 & 0.082 & 0.128 & 0.791 & 0.007 & 0.021 \\
\hline
\end{tabular}

$\sigma^{2}$ e: mean squares of experimental error or (environmental variance); $\sigma_{\text {gca: }}^{2}$ the variance of general combining ability; $\sigma_{\text {sca: }}^{2}$ the variance of specific combining ability; ${ }^{*} \sigma^{2} \mathrm{~A}$ : additive variance ${ }^{*} \overline{\mathrm{a}}$ : average degree of dominance; $\mathrm{h}_{\mathrm{b} . \mathrm{s}}^{2}$ : heritability in broad sense; $\mathrm{h}_{\mathrm{n} . \mathrm{s}}^{2}:$ heritability in narrow sense

Data in (Table 9) explain the simple correlation coefficient among all characters. The character pod number plant-1 correlated high significantly and positively with pod weight plant-1 and seed weight plant- $1 \mathrm{r}=0.597$ and 0.690 respectively, while there were significant and negative correlation between pod number plant-1 with pod length and seed weight pod-1 $\mathrm{r}=-0.512$ and -0.485 respectively. The character pod length exhibited highly significant and positive correlation with seed weight pod-1 $\mathrm{r}=0.743$, but it correlated high significantly and positively with seed weight plant-1 $r=-0.702$. The character average pod weight recorded significant and positive correlation with seed weight $\operatorname{pod}^{-1} \mathrm{r}=0.519$. Seed weight $\operatorname{pod}^{-1}$ produced significant and positive correlation with 100 -seed weight $r=0.493$, but it recorded highly significant and negative correlation with seed weight plant $^{-1} \mathrm{r}=-0.666$.

Data in (Table 10) explain the path coefficient analysis indicated to the direct and indirect effect of the character seed weight plant $^{-1}$. The character seed number pod ${ }^{-1}$ recorded maximum positive direct effect in seed weight plant ${ }^{-1}$ with 0.428 and followed by biological weight plant ${ }^{-1}$ with 0.322 . Maximum negative direct effect in seed weight plant $^{-1}$ recorded by pod length with -1.002 and followed by average pod weight with - 
0.240. Maximum positive indirect effect in seed weight plant $^{-1}$ recorded by pod length via pod number plant ${ }^{-1}$ with 0.513 and followed by pod weight plant ${ }^{-1}$ via pod number plant ${ }^{-1}$ with 0.184 . Maximum negative indirect effect was -0.744 recorded by pod length via seed weight pod $^{-1}$ and followed by -0.439 recorded by pod length via seed number pod $^{-1}$.

Table 9. Correlation coefficient among the studied characters

\begin{tabular}{|c|c|c|c|c|c|c|c|c|c|}
\hline Characters & $\begin{array}{c}\text { Pods no. } \\
\text { plant }^{-1}\end{array}$ & $\begin{array}{c}\text { Pods } \\
\text { weight }^{-1} \\
\text { plant }^{-1}(g)\end{array}$ & $\begin{array}{l}\text { Pod } \\
\text { length } \\
(\mathbf{c m})\end{array}$ & $\begin{array}{c}\text { Average } \\
\text { pod } \\
\text { weight }(g)\end{array}$ & $\underset{\text { pod }^{-1}}{\text { Seeds no. }}$ & $\begin{array}{c}\text { Seeds } \\
\text { weight } \\
\operatorname{pod}^{-1}(g)\end{array}$ & $\begin{array}{c}100 \text {-seed } \\
\text { weight } \\
\text { (g) }\end{array}$ & $\begin{array}{c}\text { Biological } \\
\text { weight } \\
\text { plant }^{-1}(\mathrm{~g})\end{array}$ & $\begin{array}{c}\text { Seeds } \\
\text { weight } \\
\text { plant }^{-1}(g)\end{array}$ \\
\hline Pods no. plant $^{-1}$ & 1.000 & & & & & & & & \\
\hline Pods weight plant ${ }^{-1}(\mathrm{~g})$ & $\begin{array}{c}0.597 \\
* *\end{array}$ & 1.000 & & & & & & & \\
\hline Pod length (cm) & $\begin{array}{c}-0.512 \\
* \\
\end{array}$ & $\begin{array}{c}0.062 \\
\text { n.s }\end{array}$ & 1.000 & & & & & & \\
\hline Average pod weight (g) & $\begin{array}{c}-0.021 \\
\text { n.s }\end{array}$ & $\begin{array}{c}0.390 \\
\text { n.s }\end{array}$ & $\begin{array}{c}0.294 \\
\text { n.s }\end{array}$ & 1.000 & & & & & \\
\hline Seeds no. pod $^{-1}$ & $\begin{array}{c}0.070 \\
\text { n.s }\end{array}$ & $\begin{array}{c}-0.135 \\
\text { n.s } \\
\end{array}$ & $\begin{array}{c}0.438 \\
\text { n.s }\end{array}$ & $\begin{array}{c}0.160 \\
\text { n.s }\end{array}$ & 1.000 & & & & \\
\hline Seeds weight pod ${ }^{-1}(g)$ & $\begin{array}{c}-0.485 \\
*\end{array}$ & $\begin{array}{c}0.089 \\
\text { n.s }\end{array}$ & $\begin{array}{c}0.743 \\
* *\end{array}$ & $\begin{array}{c}0.519 \\
*\end{array}$ & $\begin{array}{c}0.341 \\
\text { n.s }\end{array}$ & 1.000 & & & \\
\hline 100-seed weight (g) & $\begin{array}{c}-0.385 \\
\text { n.s }\end{array}$ & $\begin{array}{c}0.203 \\
\text { n.s }\end{array}$ & $\begin{array}{c}0.364 \\
\text { n.s }\end{array}$ & $\begin{array}{c}0.381 \\
\text { n.s }\end{array}$ & $\begin{array}{c}-0.311 \\
\text { n.s }\end{array}$ & $\begin{array}{c}0.493 \\
*\end{array}$ & 1.000 & & \\
\hline Biological weight plant ${ }^{-1}(\mathrm{~g})$ & $\begin{array}{c}0.267 \\
\text { n.s }\end{array}$ & $\begin{array}{c}0.215 \\
\text { n.s }\end{array}$ & $\begin{array}{c}0.286 \\
\text { n.s }\end{array}$ & $\begin{array}{c}-0.101 \\
\text { n.s }\end{array}$ & $\begin{array}{c}0.367 \\
\text { n.s }\end{array}$ & $\begin{array}{c}-0.162 \\
\text { n.s }\end{array}$ & $\begin{array}{c}-0.240 \\
\text { n.s }\end{array}$ & 1.000 & \\
\hline Seeds weight plant $^{-1}(\mathrm{~g})$ & $\begin{array}{c}0.690 \\
* *\end{array}$ & $\begin{array}{c}0.151 \\
\text { n.s }\end{array}$ & $\begin{array}{c}-0.702 \\
* *\end{array}$ & $\begin{array}{c}-0.330 \\
\text { n.s }\end{array}$ & $\begin{array}{c}-0.054 \\
\text { n.s }\end{array}$ & $\begin{array}{c}-0.666 \\
* *\end{array}$ & $\begin{array}{c}-0.408 \\
\text { n.s }\end{array}$ & $\begin{array}{c}0.224 \\
\text { n.s }\end{array}$ & 1.000 \\
\hline
\end{tabular}

Table 10. Path coefficient analysis among the studied characters

\begin{tabular}{|c|c|c|c|c|c|c|c|c|}
\hline Characters & $\begin{array}{c}\text { Pods no. } \\
\text { plant }^{-1}\end{array}$ & $\begin{array}{c}\begin{array}{c}\text { Pods weight } \\
\text { plant }^{-1}(\mathrm{~g})\end{array} \\
\end{array}$ & $\begin{array}{l}\text { Pod length } \\
\text { (cm) }\end{array}$ & \begin{tabular}{|c|} 
Average pod \\
weight (g)
\end{tabular} & \begin{tabular}{|c|}
$\begin{array}{c}\text { Seeds no. } \\
\text { pod }^{-1}\end{array}$ \\
\end{tabular} & $\begin{array}{c}\text { Seeds weight } \\
\text { pod }^{-1}(\mathrm{~g})\end{array}$ & \begin{tabular}{|c|}
$\begin{array}{c}100 \text {-seed } \\
\text { weight }(\mathrm{g})\end{array}$ \\
\end{tabular} & \begin{tabular}{|c|}
$\begin{array}{c}\text { Biological weight } \\
\text { plant }^{-1}(\mathrm{~g})\end{array}$ \\
\end{tabular} \\
\hline${\text { Pods no. } \text { plant }^{-1}}^{-1}$ & -0.078 & 0.184 & 0.513 & \begin{tabular}{|l|}
0.005 \\
\end{tabular} & \begin{tabular}{|l|}
0.030 \\
\end{tabular} & 0.024 & -0.074 & 0.086 \\
\hline $\begin{array}{c}\text { Pods weight } \\
\text { plant }^{-1}(\mathrm{~g})\end{array}$ & -0.047 & 0.308 & -0.062 & -0.094 & -0.058 & -0.004 & 0.039 & 0.069 \\
\hline Pod length $(\mathrm{cm})$ & 0.040 & 0.019 & -1.002 & -0.071 & 0.187 & -0.037 & 0.070 & 0.092 \\
\hline $\begin{array}{c}\text { Average pod } \\
\text { weight (g) }\end{array}$ & 0.002 & 0.120 & -0.294 & -0.240 & 0.068 & -0.026 & 0.073 & -0.032 \\
\hline Seeds no. pod ${ }^{-1}$ & -0.005 & -0.042 & -0.439 & -0.038 & 0.428 & -0.017 & -0.059 & 0.118 \\
\hline $\begin{array}{c}\text { Seeds weight } \\
\text { pod }^{-1}(\mathrm{~g})\end{array}$ & 0.038 & 0.027 & -0.744 & -0.125 & 0.146 & -0.050 & 0.094 & -0.052 \\
\hline $\begin{array}{c}\text { 100-seed weight } \\
\text { (g) }\end{array}$ & 0.030 & 0.063 & -0.365 & -0.092 & -0.133 & -0.025 & 0.191 & -0.077 \\
\hline $\begin{array}{c}\text { Biological } \\
\text { weight plant }^{-1}(\mathrm{~g})\end{array}$ & -0.021 & 0.066 & -0.287 & 0.024 & 0.157 & 0.008 & -0.046 & 0.322 \\
\hline
\end{tabular}

\section{Discussion}

Analysis of variance for the mean sum of square due to parents and crosses showed significant differences for all the characters studied indicating the presence of variability among parents and crosses. The mean sum of square due to progenies was significant for all the characters studied. There were no significant different among the lines. There were significant differences among the testers for seed yield plant ${ }^{-1}, 100$-seed weight and harvest index. The line $\times$ tester interaction gave significant differences for all the characters studied indicating the diversity among crosses and the prevalence of non- 
additive variance. Parents versus crosses also showed significant differences for all the characters. The present findings were quite similar with that of Ceyhan et al. (2008), Kumar et al. (2009) and Kumar et al. (2016).

Al-Hamdany (2014) reported that the General Combining Ability was significant for seed yield, 100-seed weight and pods weight but non-significant for seeds pod ${ }^{-1}$, while sca for most characters was significant in pea. Tawfiq and Abdulla (2014) carried out genetic analysis between seven pea in a half diallel crosses and showed that the variance due to specific combining ability was larger than that of general combining ability for some studied characters, while the $\mathrm{gca} / \mathrm{sca}$ variance ratio to be more than one in most studied traits, indicate the importance of additive gene effect in the inheritance of all characters.

Singh and Mishra (2002) derived information on combining ability in $10 \times 10$ diallel set. The mean sum of squares due to gca and sca variances were highly significant for all the characters except seeds $\operatorname{pod}^{-1}$. Pandey et al. (2006) reported that combining ability analysis showed significant difference for gca and sca variance for all the characters. Parent Lincoln appeared to be one of the best combiners for all the traits. The mean squares for general combining ability were observed higher than those of specific combining ability in all the characters (Singh et al., 2007).

Significant means squares due to line, crosses, half diallel, parents Vs crosses observed for yield its contributing traits. The gca/sca variance ratio were less than unity for seeds pod $^{-1}$, yield plant ${ }^{-1}, 100$-seed weight, indicating predominance of additive gene effects for these character, therefore, it is suggested that selection in $\mathrm{F}_{1}$ generation may be either following progeny or simple recurrent selection (Suman et al., 2017).

All the morphological traits showed highly significant variations among the genotypes and the variations could be used in plant improvement program. Pod length, 100 -seed weight, pods plant ${ }^{-1}$, seeds plant $^{-1}$ and seed yield plant ${ }^{-1}$ were controlled by additive gene action and selection for the improvement of these traits could be effective. Furthermore, among studied traits, four traits viz, 100-seed weight, seeds $\operatorname{pod}^{-1}$ and seeds plant ${ }^{-1}$ showed highly positive correlation and positive direct effect on seed yield. Therefore, emphasis should be given on these traits during selection in breeding program in order to increase seed yield (Khan et al., 2017).

$\mathrm{F}_{1}$ crosses had more seed yield, more plant height, more pods plant $^{-1}$, more seeds $\operatorname{pod}^{-1}$, a greater pod yield and more 100-seeds weight than the average of their parents. Heterosis was found to be significant for seed yield and its components. The values reported in this study are in agreement with the values of heterosis obtained by LejeuneHenaut et al. (1992), Mishra et al. (1993), Sarawat et al. (1994) and Ceyhan (2003) which is attributable to non-additive gene effects rather than over dominant ones.

It was found that the magnitude of sca variance $\left(\sigma^{2}\right)$ was higher than gca variance $\left(\sigma^{2}\right)$ for all the characters under studied. Hence, the ratio of $\sigma^{2}{ }_{g} / \sigma^{2}$ sas less than unity for all the characters indicating the predominant role of non-additive gene action for all the characters understudied. Similar results were also reported by Ceyhan (2006), Bora et al. (2009), Esposito et al. (2013) and Suman et al. (2017). The combining ability analysis has been the most important and efficient tool in choosing the desirable parents for hybridization programs. This technique makes it possible to classify the parental lines in terms of superiority in cross combinations and the gene action involved in the inheritance of different characters. Therefore, analysis of combining ability has been the most important and efficient tool in selecting the desirable parents for a hybridization program (Sharma et al., 2013). Singh et al. (2010) observed higher values of variance 
due to gca for pod length, and green pod yield plant ${ }^{-1}$ showed presence of additive gene action while it was non additive for pods number plant ${ }^{-1}$ based on both the generations.

The sca variance component was predominant indicating the importance of nonadditive gene effects for all the characters except for peas pod ${ }^{-1}$ and pod yield which were influenced by additive gene action, suggesting their improvement through pure line selection (Kalia and Sood, 2009). Genes are the functional units that govern the development of various characters of an individual. Gene action refers to the behavior or mode of expression of genes in a genetic population. Genes control synthesis of proteins which in turn control expression of various traits of organisms. Knowledge of gene action in plant breeding helps in the selection of parents for use in the hybridization programs and also in the choice of appropriate breeding procedure for the genetics improvement of various quantitative characters (Sharma et al., 2013).

The knowledge of gene action is very useful to a plant breeder in the selection of parents for hybridization, the estimation of some other genetic parameters and choice of breeding procedures for the genetic improvement of various quantitative characters. In an autogamous crop exploitation of non-additive genetic variance as such would be impractical. Since, the research investigation exhibited that earliness and yield attributing traits were predominantly controlled by additive gene effects, simple selection procedure like single seed descent would be effective for isolating short duration progenies in advanced generations. Simple progeny selection may be followed for selecting transgressive segregate in later generations for developing genotypes having long pods. The cross combinations involving poor $\times$ poor, good $\times$ good and poor $\times$ good general combining parents with highest significant sca effects may be obtained for different horticultural traits. Crosses having both the parents as poor general combiners may involve dominance $\times$ dominance or epistatic interaction. Such crosses may not give good transgressive segregate in later generation. The crosses involving good $\times$ good general combiners and showing high sca effects could be utilized for the purpose of developing high yielding genotypes and obtaining transgressive segregate in $F_{2}$ generation (Sharma et al., 2013).

Dhillon et al. (2006) reported additive and non-additive gene effects governed the inheritance of all the studied characters. The additive gene effects were more pronounced for pods number plant ${ }^{-1}$ and pod length, whereas the non-additive gene effects were more pronounced for seeds number pod $^{-1}$, pod yield plant $^{-1}$. Sharma and Sharma (2012) observed the prevalence of over dominance for most of the traits. Low estimates of narrow sense heritability indicated the presence of non-additive gene action for most traits. These characters also exhibited medium to high level of heritability and the selections in segregating generation could be effective for evolving early maturing types.

Sharma and Bora (2013) reported higher values of heritability in broad sense and genetic gain indicating that the additive gene actions are important in determining the characters viz. 100 green pod weights and pod yield revealed. Therefore, selection program based on these characters would be more effective in improving yield parameters of garden pea. Combining ability analysis for six physiological characters in pea revealed in some traits by additive gene action, while both additive and non-additive gene actions were important for controlling some studied traits as found by Sirohi and Singh (2013).

Seed yield plant ${ }^{-1}$ exhibited highly significant and positive correlation with 100-seed weight $(0.3775)$, pods number plant ${ }^{-1}(0.3524)$, harvest index $(0.3270)$, seeds number $\operatorname{pod}^{-1}(0.3262)$ and biological yield $(\mathrm{g})(0.2828)$. The occurrence of negative as well as positive indirect effects on yield by one or another character presents a complex 
situation where a compromise balance is required to attain proper balance of different yield components, for determining the ideotype of seed yield in field pea. The highest positive direct effect on seed yield plant $^{-1}$ was exerted by harvest index (0.7902) followed by biological yield $(\mathrm{g})(0.7820), 100$-seed weight $(0.3406)$, seeds number pod ${ }^{-1}$ (0.2788) and pods number plant ${ }^{-1}(0.2622)$ (Srivastava et al., 2018).

The genotypic correlation coefficient between different characters was generally similar in sign and nature to the corresponding phenotypic correlation coefficients in the experiment as found by Tyagi et al. (2012) and Pooja et al. (2015) also. However, in general, genotypic correlation coefficients were higher in magnitude from the corresponding phenotypic correlation coefficient values. Similar, results have been reported by Mahant et al. (2001), Arya et al. (2004) and Kumar et al. (2003). High positive direct contribution to seed yield plant $^{-1}$ was exhibited by harvest index and biological yield plant ${ }^{-1}$. However, 100-seed weight exhibited positive considerable direct effect on seed yield plant ${ }^{-1}$. Patel et al. (2006) also reported positive correlation between seed yield plant ${ }^{-1}$ with pods number plant ${ }^{-1}$ and pod length at genotypic and phenotypic level. Ghobary (2010) also obtained results that revealed; important yield components effect directly like biological yield, harvest index and 100-seed weight. The simple correlation Coefficient among characters and path analysis between seeds weight plant ${ }^{-1}$ and other characters. It was observed that the character seeds weight plant $^{-1}$ correlated positively and highly significantly with the character pods number plant ${ }^{-1}$, pods weight plant $^{-1}$, biological weight plant $^{-1}$ and harvest index recording $(0.857,0.839,0.694$ and $0.505)$ respectively. The character biological weight plant ${ }^{-1}$ and harvest index exhibited maximum positive direct effect in seeds weight plant $^{-1}$ recording $(0.630$ and 0.456$)$ respectively, the character pods number plant ${ }^{-1}$ showed the highest positive indirect effect in seeds weight plant ${ }^{-1}$ via harvest index recording (0.191) (Tofiq et al., 2015).

All the characters showed moderate to low phenotypic and genotypic coefficient of variation. Genotypic coefficient of variation was the highest for 100 -seed weight (37.24) followed by seeds plant ${ }^{-1}$ (15.27). 100-seed weight had the highest heritability (95.97). Pod length, 100-seed weight, pods plant ${ }^{-1}$ and seeds plant $^{-1}$ showed significant positive genotypic and phenotypic correlation with seed yield. In path analysis, 100seed weight, seeds number pod $^{-1}$ and seeds plant ${ }^{-1}$ showed positive direct effect on yield. Considering genetic variability, correlation and path analysis, emphasis should be given on pod length, seeds pod $^{-1}$, seeds plant $^{-1}$ and 100-seed weight during breeding program to improve seed yield of pea (Khan et al., 2017).

\section{Conclusion}

The preponderance of non-additive type of gene action clearly indicated that selection of superior plants should be postponed to later generation. It could be clear that non-additive genetic variance is considered to be the major source of the total genetic variance responsible for the inheritance of most of the studied characters except average pod weight and 100-seed weight. The crosses involving (good $\times$ good) general combiners and showing high sca effects could be utilized for the purpose of developing high yielding genotypes and obtaining transgressive segregation in $\mathrm{F}$ generation. The high values of average degree of dominance for almost all of the studied characters which were more than unity confirm the superiority of non-additive gene effect in the inheritance of the studied characters which make the hybridization to be the method to improve these characters. 


\section{Recommendation}

Continuous breeding programs are required to reveals pea cultivars for high yielding crosses like Avolla $\times$ Joneor. Further works is recommended to fix the desirable genes respect both forage and seed yield. More investigation were required to evaluate more pea cultivars at autumn and spring seasons which survival potential to the climatically conditions prevailing in Sulaimani region.

\section{REFERENCES}

[1] Al-Hamdany, H. S. Y. (2014): Estimation of heterosis, combining ability, gene action, genotypic and phenotypic correlation in pea (Pisum sativum L.). - Jordan J. of Agri. Sci. 10(2).

[2] Al-Mohammad, F., Al-Yonis, M. A. (2000): Agricultural Experimentation Design and Analysis. Parts 1 and 2. - Baghdad University, Ministry of Higher Education and Scientific Research, Baghdad. pp. 374 and 444 (in Arabic).

[3] Arya, S., Malik, B. P. S., Kumar, R., Dhari, R. (2004): Variability, correlation and path analysis in field pea (Pisum sativum L.). - Haryana Agric. Univ. J. of Res 34(2): 149-53.

[4] Askander, H. S., Abdullah, P. A., Abdulrahman, R. I. S. (2018): Estimation some genetic parameters, combining ability and heterosis in pea (Pisum sativum L.) using half diallel crosses. - Journal of University of Duhok (Agri. and Vet. Sciences) 21(1): 19-28. https://doi.org/10.26682/avuod. 21.1.3.

[5] Basbag, S., Ekinci, R., Gencer, O. (2007): Combining ability and heterosis for earliness characters in line $\times$ tester population of (Gossypium hirsutum L.). - Hereditas 144: 185190.

[6] Bora, L., Kumar, V., Maurya, S. K. (2009): Hybrid breeding for green pod quality, yield and its components in garden pea (Pisum sativum L.). - Ann. Hort. 2(2): 161-165.

[7] Ceyhan, E. (2003): Determination of Some Agricultural Characters and Their Heredity Through Line $\times$ Tester Method in Pea Parents and Crosses. - Selcuk Univ., Graduate School Nat. Appl. Sci., Konya.

[8] Ceyhan, E. (2006): Combining abilities for grain yield and leaf characters in pea parents and crosses. - Selçuk Tarım Bilimleri Dergisi 20(40): 83-89.

[9] Ceyhan, E., Avci, M. A. (2005): Combining ability and heterosis for grain yield and some yield components in pea (Pisum sativum L.). - Pak. J. Biol. Sci. 8(10): 1447-1452.

[10] Ceyhan, E., Avci, M. A., Karadas, S. (2008): Line $\times$ tester analysis in pea (Pisum sativum L.): Identification of superior parents for seed yield and its components. - Afr. J. Biotechnol. 7(16): 2810-2817.

[11] Dhillon, T. S., Singh, M., Singh, H. (2006): Combining ability studies of genetically diverse lines in garden pea. - Haryana J. Hort. Sci. 35(3/4): 334-337.

[12] Esposito, M. A., Gatti, I., Cravero, V. P., Anido, F. S. L., Cointry, E. L. (2013): Combining abilities and heterotic groups in (Pisum sativum L.). - Australian J. Crop Sci. 7(11): 1634-1641.

[13] Ghobary, H. M. M. (2010): Study of relationship between yield and some yield components in garden pea (Pisum sativum L.) by using correlation and path analysis. $-\mathrm{J}$. Agric. Res. 36: 351-360.

[14] Haque, S. R., Akter, N., Khan, M. A. H., Kabir, K., Islam, M. M. (2014): Yield potential of garden pea varieties at varied harvesting time. - Bangladesh Agron. J. 17(2): 21-28.

[15] Kalia, P., Sood, M. (2009): Combining ability in the $F_{1}$ and $F_{2}$ generations of a diallel cross for horticultural traits and protein content in garden pea (Pisum sativum L.). SABRAO J. Breed. Genet. 41(1): 53-68.

[16] Kempthorne, O. (1957): An Introduction to Genetic Statics. - John Wiley and Sons, Inc., New York, pp. 468-473. 
[17] Khan, R. A., Mahmud, F., Reza, M. A., Mahbub, M., Shirazy, B. J., Rahman, M. M. (2017): Genetic diversity, correlation and path analysis for yield and yield components of pea (Pisum sativum L.). - World Journal of Agricultural Sciences 13(1): 11-16. DOI: 10.5829/idosi.wjas.

[18] Kumar, B., Ram, L., Singh, J. D., Singh, B. (2003): Correlations and path coefficient analysis in pea (Pisum sativum L.). - Prog. Agric. 3(1/2): 141-142.

[19] Kumar, C. S., Sreelakshmi, C. H., Varma, P. K. (2009): Studies on combining ability and heterosis in pigeon pea (Cajanus cajan L.). - Legume Res. 32(2): 92-97.

[20] Kumar, D., Malik, S., Kumar, A., Singh, S. K., Kumar, S. (2016): Studies on combining ability through line $\times$ tester analysis in garden pea (Pisum sativum L.). - Ann. Hort. 9(1): 64-72.

[21] Lejeune-Henaut, I., Fouilloux, G., Ambrose, M. J., Dumoulin, V., Eteve G. (1992): Analysis of a 5 parent half diallel in dried pea (Pisum sativum L.) I. Seed yield heterosis. - Agronomie 12: 545-550.

[22] Mahant, I. C., Senapati, N., Samal, K. M., Dhal, A. (2001): Genetic variability performance, character association and co-heritability in field pea (Pisum sativum L.). Legume Res. 24(2): 92-96.

[23] Mahbub, M. M., Rahman, M. M., Hossain, M. S., Nahar, L., Shirazy, B. J. (2016): Morpho physiological Variation in Soybean (Glycine max L. - Merrill). AmericanEurasian J. Agri. \& Environ. Sci. 16(2): 234-238.

[24] Makasheva, R. K. H. (1983): The pea Oxinion press pvt. - Ltd. New Delhi, pp: 267.

[25] Mishra, S. P., Asthana, A. N., Lallan, G. S. (1993): Heterosis for yield and yield components in field pea. - Heterosis Breeding in Crop Plants - Theory and Application: Short Communications, Symposium, Ludhiana, 23-24 February, pp. 42-43.

[26] Nawab, N. N., Subhani, G. M., Mahmood, K., Shakil, Q., Saeed, A. (2008): Genetic variability, correlation and path analysis studies in garden pea (Pisum sativum L.). - J. Agri. Res. 46(4): 333-340.

[27] Pandey, V., Pant, T., Das, S. C. (2006): Studies on heterosis and combining ability in pea. - Indian J. Hort. 63(3): 338-340.

[28] Patel, P. J., Patel, N. H., Prajapati, B. H., Tikka, S. B. S., Patel, P. T. (2006): Correlation and path-analysis in field pea (Pisum sativum L.). - Indian J. of Pulses Res. 19(1): 109110.

[29] Pooja, P., Singh, N., Rawat, M. (2015): Study of genetic variation, heritability and correlation in vegetable pea (Pisum sativum L.). - The Bioscan 10(4): 2131-2133.

[30] Sarawat, P., Stoddard, F. L., Marshall, D. R., Ali (1994): Heterosis for yield and related characters in pea. - Euphytica 80: 39-48.

[31] Sharma, B. B., Sharma, V. K. (2012): Genetic analysis for earliness and yield traits in garden pea (Pisum sativum L.). - Vegetos 25(1): 63-67.

[32] Sharma, B. B., Sharma, V. K., Dhakar, M. K., Punetha, S. (2013): Combining ability and gene action studies for horticultural traits in garden pea: a review. - African Journal of Agricultural Research 8(38): 4718-4725. DOI: 10.5897/AJAR2013.7268.

[33] Sharma, V. K., Bora, L. (2013): Studies on genetic variability and heterosis in vegetable pea (Pisum sativum L.) under high hills condition of Uttarakhand, India. - Afr. J. Agric. Res. 8(18): 1891-1895.

[34] Singh, D., Mishra, V. K. (2002): Combining ability studies through diallel in pea (Pisum sativum L.). - Legume Res. 25(2): 105-108.

[35] Singh, H., Singh, M., Brar, P. S. (2007): Assessment of combining ability for some quantitative characters in edible podded pea (Pisium sativum var. macrocarpum). - Crop Improvement 34(1): 106-109.

[36] Singh, K. P., Singh, H. C., Verma, M. C. (2010): Genetic analysis for yield and yield traits in pea. - J. Food Legumes 23(2): 113-116.

[37] Singh, R. K., Chaudhary, B. D. (1985): Biometrical Methods in Quantitative Genetic Analysis. - Kalyani Publisher, New Delhi. 
[38] Sirohi, A., Singh, S. K. (2013): Studies on combining ability for leaf area, specific leaf weight and chlorophyll content in field pea. - Adv. Plant Sci. 26(1): 85-87.

[39] Smykal, P., Aubert, G., Bustin, J., Coyne, C., Ellis, N., Flavell, A., Warkentin, T. (2012): Pea (Pisum sativum L.) in the genomics era. - Agronomy 2:(2): 74-115.

[40] Srivastava, A., Sharma, A., Singh, T., Kumar, R. (2018): Correlation coefficient and path coefficient in field pea (Pisum sativum L.). - Int. J. Curr. Microbiol. App. Sci. 7(02): 549553.

[41] Suman, H., Kumar, B., Nageshwar, Rathi, M., Tamatam, D. (2017): Heterosis and combining ability for grain yield and yield associated traits in $10 \times 10$ diallel analysis in pea (Pisum sativum L.). - International Journal of Current Microbiology and Applied Sciences 6(12): 1574-1585.

[42] Tampha, S., Jeberson, M. S., Sastry, E. V. D., Shashidhar, K. S., Sharma, Ph. R. (2018): Line $\times$ tester analysis for yield and its contributing characters in field pea (Pisum sativum L.). - The Pharma Innovation Journal 7(9): 104-109.

[43] Tawfiq, Sh. I., Abdulla, S. M. S. (2014): Genetic analysis for seven pea varieties and their half diallel hybrids for forage and seed yield. - J. of Zankoy Sulaimani-Part A, 16(special issue).

[44] Tofiq, S. E., Abdulkhaleq, D. A., Hama Amin, T. N., Azez, O. K. (2015): Correlation and path coefficient analysis in seven field pea (Pisum sativum L.) genotypes created by half diallel analysis in Sulaimani region for $\mathrm{F}_{2}$ generation. - International Journal of Plant, Animal and Environmental Sciences 5(4).

[45] Tyagi, N., Singh, A. K., Rai, V. P., Kumar, S., Srivastava, C. P. (2012): Genetic variability studies for lodging resistance and yield attributes in pea (Pisum sativum L.). J. Food Leg. 25(3): 179-182.

[46] Yoshida, H., Tomiyama, Y., Tanaka, M., Mizushina, Y. (2007): Distribution of fatty acids in triacylglycerols and phospholipids from peas (Pisum sativum L.). - Journal of the Science of Food and Agriculture No. 87: 2709-2714. 